\title{
Methane Carbon Supports Aquatic Food Webs to the Fish Level
}

\author{
Angela M. Sanseverino ${ }^{1,2 *}$, David Bastviken ${ }^{2}$, Ingvar Sundh ${ }^{3}$, Jana Pickova ${ }^{4}$, Alex Enrich-Prast ${ }^{1,2}$ \\ 1 Institute of Biology, University Federal of Rio de Janeiro, Rio de Janeiro, Brazil, 2 Department of Thematic Studies-Water and Environmental Studies, Linköping \\ University, Linköping, Sweden, 3 Uppsala BioCenter, Department of Microbiology, Swedish University of Agricultural Sciences, Uppsala, Sweden, 4 Uppsala BioCenter, \\ Department of Food Science, Swedish University of Agricultural Sciences, Uppsala, Sweden
}

\begin{abstract}
Large amounts of the greenhouse gas methane $\left(\mathrm{CH}_{4}\right)$ are produced by anaerobic mineralization of organic matter in lakes. In spite of extensive freshwater $\mathrm{CH}_{4}$ emissions, most of the $\mathrm{CH}_{4}$ is typically oxidized by methane oxidizing bacteria (MOB) before it can reach the lake surface and be emitted to the atmosphere. In turn, it has been shown that the $\mathrm{CH}_{4}$-derived biomass of $\mathrm{MOB}$ can provide the energy and carbon for zooplankton and macroinvertebrates. In this study, we demonstrate the presence of specific fatty acids synthesized by MOB in fish tissues having low carbon stable isotope ratios. Fish species, zooplankton, macroinvertebrates and the water hyacinth Eichhornia crassipes were collected from a shallow lake in Brazil and analyzed for fatty acids (FA) and carbon stable isotope ratios $\left(\delta^{13} \mathrm{C}\right)$. The fatty acids $16: 1 \omega 8 \mathrm{c}, 16: 1 \omega 8 \mathrm{t}, 16: 1 \omega 6 \mathrm{c}, 16: 1 \omega 5 \mathrm{t}$, $18: 1 \omega 8 \mathrm{c}$ and $18: 1 \omega 8 \mathrm{t}$ were used as signature for $\mathrm{MOB}$. The $\delta^{13} \mathrm{C}$ ratios varied from $-27.7 \%$ to $-42.0 \%$ and the contribution of MOB FA ranged from $0.05 \%$ to $0.84 \%$ of total FA. Organisms with higher total content of MOB FAs presented lower $\delta^{13} \mathrm{C}$ values (i.e. they were more depleted in ${ }^{13} \mathrm{C}$ ), while organisms with lower content of MOB signature FAs showed higher $\delta^{13} \mathrm{C}$ values. An UPGMA cluster analysis was carried out to distinguish grouping of organisms in relation to their MOB FA contents. This combination of stable isotope and fatty acid tracers provides new evidence that assimilation of methanederived carbon can be an important carbon source for the whole aquatic food web, up to the fish level.
\end{abstract}

Citation: Sanseverino AM, Bastviken D, Sundh I, Pickova J, Enrich-Prast A (2012) Methane Carbon Supports Aquatic Food Webs to the Fish Level. PLoS ONE 7(8): e42723. doi:10.1371/journal.pone.0042723

Editor: David L. Kirchman, University of Delaware, United States of America

Received March 14, 2012; Accepted July 10, 2012; Published August 7, 2012

Copyright: (c) 2012 Sanseverino et al. This is an open-access article distributed under the terms of the Creative Commons Attribution License, which permits unrestricted use, distribution, and reproduction in any medium, provided the original author and source are credited.

Funding: Financial support was contributed by Coordination for the Improvement of Higher Education Personnel CAPES (http://www.capes.gov.br), the Brazilian Science Council CNPq (http://www.cnpq.br), and Carlos Chagas Filho Foundation for Research Support of Rio de Janeiro State FAPERJ (http://www.faperj.br) to AEP and AMS and by the Swedish Research Council VR (http://www.vr.se) to DB. The funders had no role in study design, data collection and analysis, decision to publish, or preparation of the manuscript.

Competing Interests: The authors have declared that no competing interests exist.

*E-mail: angelamsanseverino@gmail.com

\section{Introduction}

Methane $\left(\mathrm{CH}_{4}\right)$ is the terminal product of anaerobic respiration when all electron acceptors except carbon dioxide $\left(\mathrm{NO}_{3}{ }^{-}, \mathrm{Mn}^{+4}\right.$, $\mathrm{Fe}^{+3}$ and $\mathrm{SO}_{4}{ }^{-2}$ ) have been depleted by the microbial community. The production of methane is performed by methanogens, which are microorganisms belonging to the domain Archaea.

In 1906, Sohngen [1] showed for the first time that $\mathrm{CH}_{4}$ can serve as an energy and carbon source for bacteria. Biological oxidation of $\mathrm{CH}_{4}$ is now known to occur aerobically in both terrestrial and aquatic habitats [2], and anaerobically in sediments and anoxic salt water [3]. The aerobic methane oxidizing bacteria (MOB) have been classified into the phylum Proteobacteria and recently also Verrucomicrobia (based on three strains), the latter representing thermophilic acidophiles and still being under taxonomic debate [4]. The MOB in Proteobacteria have 16 recognized genera within the classes Gammaproteobacteria (traditionally referred to as "Type I" MOB) and Alphaproteobacteria ("Type II" MOB) [5,6], although some genera do not fit these generalizations very well [4].

Aquatic food webs are supported by organic matter derived from phytoplankton, macrophytes or imported from the surrounding land (allochthonous sources) [7,8]. $\mathrm{CH}_{4}$ production accounts for a large proportion of the total organic matter degradation in freshwater lakes (20-56\%) [9], and is a source of energy and carbon for aerobic MOB in the water column and the sediment, linking the anoxic and oxic communities [10-12].

Isotopic distributions in animals are generally closely related to dietary isotopic composition [13]. The stable isotopic compositions of animal tissues reflect both long-term and short-term diets in slow and fast turnover tissues [14]. Measurement of carbon stable isotope ratios $\left(\delta^{13} \mathrm{C}\right)$ has been a successful tool in food web studies [15-17]. Because $\mathrm{CH}_{4}$ is much depleted in ${ }^{13} \mathrm{C}$, low $\delta^{13} \mathrm{C}$ values in organisms of aquatic food webs have been considered to indicate their consumption of $\mathrm{CH}_{4}$-derived carbon [10,11]. Such low values of $\delta^{13} \mathrm{C}$ in animal biomass have been reported for invertebrates in various aquatic systems [11,15,18-22].

Low $\delta^{13} \mathrm{C}$ values have been reported for fish, and a few studies have suggested that $\mathrm{CH}_{4}$-derived carbon could be transferred in substantial amounts to higher trophic levels [11,23-26]. Calheiros ([25] unpublished data) found strongly negative $\delta^{13} \mathrm{C}$ values for zooplankton, aquatic insects and detritivorous fishes in a Brazilian Pantanal lake, being the first study to discuss the importance of methanotrophs for the whole food web in this wetland.

While more negative $\delta^{13} \mathrm{C}$ values can be an indicator of $\mathrm{CH}_{4}$ carbon, the isotopic signal from other potential sources of ${ }^{13} \mathrm{C}$ depleted carbon - such as primary production based on $\mathrm{CO}_{2}$ from respiration [27] - can provide alternative explanations [16,17]. 
Therefore, the combination of stable isotope analysis with other independent biomarkers is needed to elucidate if low $\delta^{13} \mathrm{C}$ values are due to assimilation of carbon from biogenic $\mathrm{CH}_{4}[11,28]$.

The lipids of the proteobacterial MOB have special fatty acid (FA) composition $[5,6,29,30]$. They contain a few very unusual FAs that have been used as efficient group-specific markers in studies of abundance and dynamics in methanotrophic community structure [31,32]. A fraction of the assimilated FAs of prey organisms is stored in cells rather than being degraded and the chain lengths and double bond positions in such stored FAs are preserved [33]. On a general level, variation in the FA composition using specific MOB FA can be used as a traceability tool for determining the relative dependency on bacteria versus phytoplankton in diets [34] and seasonal variation in food quality used by zooplankton [35].

Similarly, monounsaturated fatty acids, like those diagnostic for $\mathrm{MOB}$, can thus be microbial biomarkers indicating transfer of carbon and energy from methane to higher food web levels. The assumption that animals actually ingest MOB has been supported by the detection of phospholipid fatty acids (PLFAs) diagnostic for MOB in tissues of chironomid larvae [36]. In addition, Deines et al. [18] experimentally confirmed that MOB carbon can be transferred to invertebrate animals. In this way, findings that FAs specific for $\mathrm{MOB}$ are present in tissues of ${ }^{13} \mathrm{C}$-depleted freshwater invertebrates have been supporting the hypothesis of a link between MOB and animal food webs [36]. However, MOB specific FAs have not been reported in fishes so far.

In this study, we tested the hypothesis that methane carbon from $\mathrm{MOB}$ can be transferred through food webs all the way to fish, by combining analyses of $\delta^{13} \mathrm{C}$ and fatty acid composition in fish, benthic macroinvertebrates, zooplankton, and the dominating aquatic macrophyte from a shallow tropical lake in Pantanal, Brazil. We found specific fatty acids of methane-oxidizing bacteria in tissues of aquatic invertebrates and fish, showing that methane can in fact contribute carbon to large parts of aquatic food webs and production of fish biomass.

\section{Results and Discussion}

All $\delta^{13} \mathrm{C}$ values ranged from -42.0 to $-27.7 \%$ and the contribution of MOB FA varied from 0.05 to $0.84 \%$ of total FA (Figure 1). Based on previous studies the FAs 16:1 $1 \omega 8 \mathrm{c}, 16: 1 \omega 8 \mathrm{t}$, $16: 1 \omega 6 \mathrm{c}, 16: 1 \omega 5 \mathrm{t}, 18: 1 \omega 8 \mathrm{c}$ and 18:1 $1 \omega 8 \mathrm{t}$ are signature FAs for MOB $[29,30]$. The total contribution of these FAs was higher in organisms with low $\delta^{13} \mathrm{G}$ (Table 1, Figure 1). Two discrete groups arose in Figure 1: (A) organisms with a higher total content of MOB signature FAs and lower $\delta^{13} \mathrm{C}$ values, and (B) organisms with lower content of MOB signature FAs and higher $\delta^{13} \mathrm{C}$ values. The former group includes Ceratopogonidae and the fish Anadoras grypus with the highest contribution of MOB fatty acids (0.84 and $0.79 \%$, respectively), Chironomidae sp.1 (0.73\%), Cyphocharax sp. $(0.71 \%)$ and the ephemeropteran Campsurus sp. (0.66\%). These five organisms were also depleted in ${ }^{13} \mathrm{C}\left(\delta^{13} \mathrm{C}\right.$ of $-38.1,-36.5$, $-37.1,-36.1$ and $-39.7 \%$, respectively). All these organisms can feed at oxic-anoxic interfaces where MOB abundance is likely to be high [10], which provides an explanation to the comparatively high consumption and incorporation of $\mathrm{MOB}$ carbon into their biomass. Zooplankton and Chaoborus sp. showed the lowest $\delta^{13} \mathrm{C}$ values ( -42.0 and $40.2 \%$, respectively) and a MOB-specific FA contribution of 0.45 and $0.50 \%$, respectively. Calheiros ([25] unpublished data) also found low values of $\delta^{13} \mathrm{C}$ in zooplankton $(-42.7$ to $-31.6 \%$ o), benthic chironomids $(-62$ to $-49 \%$ ) and ephemeropterans $(-41.4$ to $-34.3 \%$ o $)$ in another Pantanal lake, suggesting an assimilation of biogenic $\mathrm{CH}_{4}$. Other taxa in group A include the fishes Potamorhina squamoralevis, Crenicichla sp., Leporinus friderici and Steindachnerina brevipinna which had equally low $\delta^{13} \mathrm{C}$ values $\left(\delta^{13} \mathrm{C}<-36 \%\right.$ ) and a range of MOB-specific FA content from 0.43 to $0.66 \%$. These fishes can all have benthivorous and omnivorous or detritivorous feeding habits, except Crenicichla sp., which is mainly carnivorous.

A higher variability in FA composition than in $\delta^{13} \mathrm{C}$ could be explained by physiological differences among taxa regarding to what extent various FAs are metabolized or stored in muscle tissue. Branched FA are often difficult to metabolize and can therefore be magnified in the tissues. Lipid composition in fish muscle varies mainly with fish diet. The metabolism of total lipids and fatty acids might be related to age, sex, reproductive cycle and capture period of the fish and influenced by environmental factors as seasonal hydrological cycle and food availability [37]. Besides, lipids are unevenly stored among tissue types throughout the year. Differences in migratory behavior and life history may explain distinctive lipid dynamics among fish species [38]. In addition, some organisms might have a more homogeneous diet which could lead to a lower isotopic variation. Calheiros ([25] unpublished data) reported low $\delta^{13} \mathrm{C}$ values for $P$. squamoralevis (mean $-36.9 \%$ ) and small variations in isotopic signals among seasons, which could be due to a more specialized diet. Wantzen [24] pointed out that seasonal variations in isotopic signal of fish species in Pantanal were more prominent in less specialized omnivores, invertivores and some carnivores, while more specialized detritivores and herbivores appeared to be more influenced by $\delta^{13} \mathrm{C}$ changes in the diet affected by biogeochemical processes.

Group B (Figure 1), formed by the less ${ }^{13} \mathrm{C}$-depleted fish species Tetragonopterus argenteus (-27.7\%o), Astyanax cf. bimaculatus (-28.0\%o)

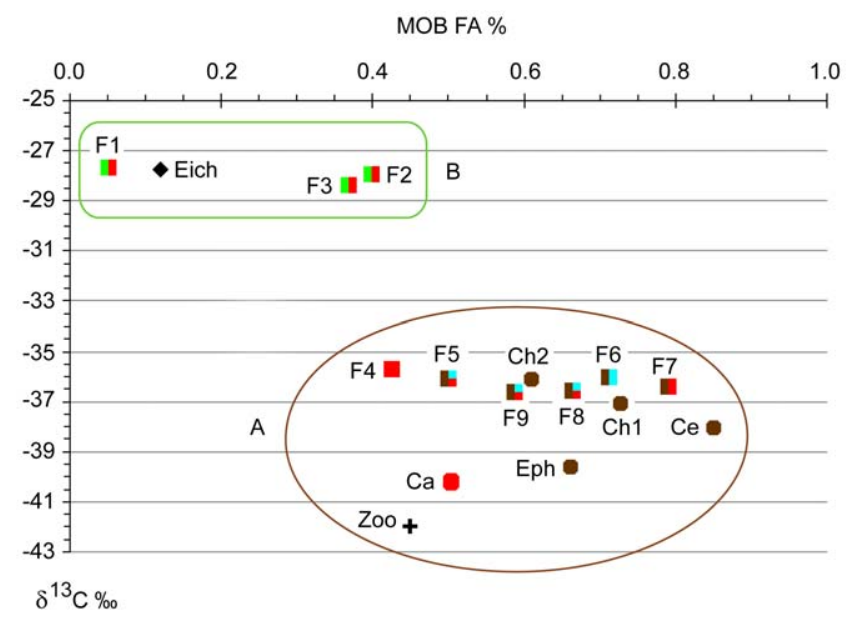

Figure 1. Methane oxidizing bacteria fatty acids (MOB FA \%) and carbon isotope ratios $\left(\delta^{13} \mathrm{C} \%\right)$ in organisms. MOB FA \% represents the sum of the MOB fatty acid markers $16: 1 \omega 8 c, 16: 1 \omega 8 t$, $16: 1 \omega 6 c, 16: 1 \omega 5 \mathrm{t}, 18: 1 \omega 8 \mathrm{c}$ and 18:1 $108 \mathrm{t}$, expressed as percentage of total fatty acids. Ca- Chaoborus sp., Ce- Ceratopogonidae, Ch1Chironomidae sp.1, Ch2- Chironomidae sp.2, Eph- Campsurus sp., F1Tetragonopterus argenteus, F2- Astyanax cf. bimaculatus, F3- Parauchenipterus galeatus, F4- Crenicichla sp., F5- Potamorhina squamoralevis, F6Cyphocharax sp., F7- Anadoras grypus, F8- Leporinus friderici, F9Steindachnerina brevipinna, Eich- Eichhornia crassipes, Zoo- Zooplankton. Fishes are represented by squares, macroinvertebrates by circles, zooplankton by cross and the plant by diamond. The different colors indicate the type of food sources expected to dominate: green indicates herbivory on plant material, blue herbivory on bottom filamentous algae, red carnivory and brown detritivory. Other types of feeding may occur and can result in variability. The data points separate into two major groups, denoted A and B.

doi:10.1371/journal.pone.0042723.g001 
Table 1. Isotope ratios of carbon and contribution of the methane oxidizing bacteria fatty acid markers.

\begin{tabular}{|c|c|c|c|c|c|c|c|c|}
\hline Organisms & $\delta^{13} \mathrm{C}$ & $16: 1 \omega 8 c$ & $16: 1 \omega 8 t$ & $16: 1 \omega 6 c$ & $16: 1 \omega 5 t$ & $18: 1 \omega 8 c$ & $18: 1 \omega 8 t$ & MOB FA $\%$ \\
\hline Eichhornia crassipes & -27.8 & 0.0546 & 0.00098 & 0.00977 & 0.00559 & 0.043 & 0.0081 & 0.12 \\
\hline \multicolumn{9}{|l|}{ Invertebrates } \\
\hline Chironomidae sp.1 & -37.1 & 0.242 & 0 & 0.0862 & 0.153 & 0.23 & 0.0175 & 0.73 \\
\hline Chironomidae sp.2 & -36.2 & 0.209 & 0.00886 & 0.0533 & 0.0938 & 0.236 & 0.0102 & 0.61 \\
\hline Chaoborus sp. & -40.2 & 0.0432 & 0 & 0.0199 & 0.0146 & 0.428 & 0 & 0.50 \\
\hline Ceratopogonidae & -38.1 & 0.32 & 0.02 & 0.0856 & 0.17 & 0.237 & 0.0094 & 0.84 \\
\hline Campsurus sp. & -39.7 & 0.0697 & 0.00881 & 0.0648 & 0.268 & 0.248 & 0 & 0.66 \\
\hline Zooplankton & -42.0 & 0.118 & 0 & 0.0102 & 0.0106 & 0.308 & 0 & 0.45 \\
\hline \multicolumn{9}{|l|}{ “Fishes” } \\
\hline Tetragonopterus argenteus & -27.7 & 0.00565 & 0 & 0.00223 & 0.00763 & 0.0239 & 0.0074 & 0.05 \\
\hline Astyanax cf.bimaculatus & -28.0 & 0.184 & 0 & 0.0272 & 0.0804 & 0.106 & 0 & 0.40 \\
\hline Parauchenipterus galeatus & -28.4 & 0.155 & 0 & 0.0344 & 0.103 & 0.0742 & 0 & 0.37 \\
\hline Crenicichla sp. & -35.8 & 0.179 & 0 & 0.0363 & 0.105 & 0.113 & 0 & 0.43 \\
\hline Potamorhina squamoralevis & -36.1 & 0.177 & 0 & 0.0596 & 0.0903 & 0.174 & 0 & 0.50 \\
\hline Cyphocharax sp. & -36.1 & 0.304 & 0 & 0.0906 & 0.147 & 0.168 & 0 & 0.71 \\
\hline Anadoras grypus & -36.5 & 0.183 & 0 & 0.0682 & 0.0914 & 0.45 & 0 & 0.79 \\
\hline Leporinus friderici & -36.6 & 0.28 & 0 & 0.0801 & 0.222 & 0.0817 & 0 & 0.66 \\
\hline Steindachnerina brevipinna & -36.7 & 0.238 & 0 & 0.0988 & 0.145 & 0.105 & 0 & 0.59 \\
\hline
\end{tabular}

$\delta^{13} \mathrm{C}$, carbon stable isotope ratios relative to the PeeDee Belemnite standard and expressed as a per mil (\%) deviation; MOB FA, methane oxidizing bacteria fatty acid markers $16: 1 \omega 8 c, 16: 1 \omega 8 t, 16: 1 \omega 6 c, 16: 1 \omega 5 t, 18: 1 \omega 8 c$ and $18: 1 \omega 8 t$, expressed as percentage of total fatty acids. MOB FA \% represents the sum of the MOB FA markers. doi:10.1371/journal.pone.0042723.t001

and Parauchenipterus galeatus (-28.4\%o), had lower contents of MOB-specific FA $(0.05,0.40$ and $0.37 \%$, respectively). The higher $\delta^{13} \mathrm{C}$ values in combination with lower MOB FA content of these three fishes indicate a lower incorporation of MOB biomass. This conclusion is in accordance with their feeding habits. These taxa are known to be pelagic or living close to aquatic plants, presenting omnivorous habits with tendency to herbivory-invertivory $[39,40]$. Wantzen et al. [24] found similar isotopic signatures for $T$. argenteus and $A$. bimaculatus in Pantanal. Although aquatic $\mathrm{C}_{4}$ plants were not the major carbon source, they suggested that at least part of the $A$. bimaculatus diet would be derived from aquatic $\mathrm{C}_{4}$ grasses, which have higher $\delta^{13} \mathrm{C}$ values than $\mathrm{C}_{3}$ plants and occur in small patches among large mats of $\mathrm{C}_{3}$ macrophytes [24]. The water hyacinth Eichhornia crassipes, a $\mathrm{C}_{3}$ plant that totally dominates the macrophyte community in the studied environment, had a similar $\delta^{13} \mathrm{C}$ signature (-27.8\%o). Therefore, a combination of carbon sources from $\mathrm{C}_{3}$ plants, $\mathrm{C}_{4}$ plants and $\mathrm{MOB}$ could yield a ${ }^{13} \mathrm{C}$ signature similar to $\mathrm{C}_{3}$ plants.

Traces of MOB FA found in plant samples might have two different causes. First, MOB FA in plant samples could be due to the difficulty to completely remove biofilms from the plant surface, especially those attached to the submerged roots. Secondly, there are studies that revealed the presence of MOB inside living tissues of submerged aquatic plants (Sphagnum mosses) [41,42]. Methanederived carbon was incorporated into plant lipids when mosses were submerged [42]. Even though $E$. crassipes is a floating macrophyte and not a moss, we cannot exclude the possibility of this phenomenon.

The dendrogram in Figure 2 illustrates the clustering of organisms based on contributions of the different MOB FAs only (i.e. with no consideration to ${ }^{13} \mathrm{C}$ signatures). In contrast to the grouping based on total MOB FA and ${ }^{13} \mathrm{C}$ values illustrated in Figure 1, this clustering approach depends on the relative contribution of the individual MOB FAs, but yields a similar overall result. Four arbitrary "cutoff" lines, at Bray-Curtis similarities of $0.4,0.6,0.8$ and 0.87 were used as reference points for identifying clusters.

At a similarity of 0.4 , two distinct clusters can be seen. Cluster 1 grouped organisms with the lowest contributions of MOB FA, i.e. $E$. crassipes and $\mathcal{T}$. argenteus. This is in accordance with the fact that $T$. argenteus is an omnivorous fish with tendency to herbivoryinsectivory, feeding mainly on vascular plants [43], plant debris and terrestrial insects [39,44]. Cluster 2 was formed by all other organisms with higher MOB FA values.

At a similarity of 0.6 , cluster 2 was divided into two new clusters: One had a high contribution of the FA $18: 1 \omega 8 \mathrm{c}$, which is highly specific for type II MOB [5], and was therefore named Type II $M O B$. The other cluster was based on high contribution of specific FA markers for MOB type I, and named Type I MOB. Inside cluster Type II MOB, Chaoborus sp. and zooplankton were grouped together since they presented the highest contributions of $18: 1 \omega 8 \mathrm{c}$ $(84.6 \%$ and $68.9 \%$, of the total MOB FA, respectively), followed by $A$. grypus ( $56.7 \%$ of the total MOB FA). Chaoborid larvae are zooplankton predators, whose preferred food source are microcrustaceans, although they eat a wide variety of animals including dipteran larvae, oligochaetes, rotifers, other chaoborids [45] and even dinoflagellates [46]. It should be noted that zooplankton in this shallow tropical lake are not restricted to autotrophic or heterotrophic production in the water column, but can also access food items from surface sediments which are frequently resuspended, and from the biofilms in the root zone of floating $E$. crassipes. Anadoras grypus is an invertivore, bottom-feeding fish [47].

Within cluster Type I MOB, three clusters were identified at a "cutoff" similarity of 0.8 :

a) The ephemeropteran Campsurus sp. which showed the highest content of the FA 16:1 155 t. Nymphs of Campsurus are bottom 


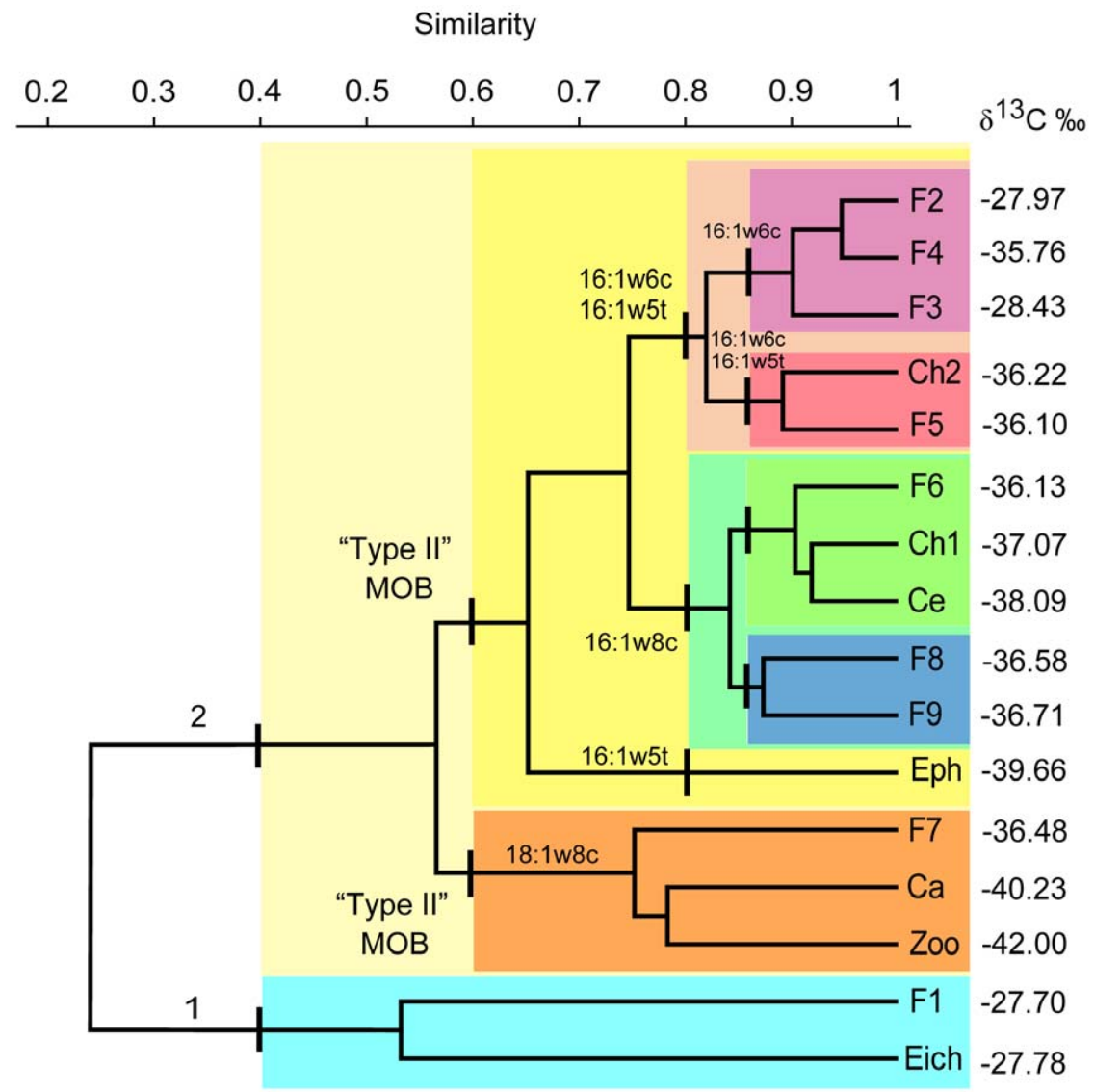

Figure 2. Dendrogram from UPGMA cluster analysis based on a Bray-Curtis similarity matrix of organisms according to MOB FA contributions. The isotope ratios of carbon $\left(\delta^{13} \mathrm{C} \%\right.$ vs. PDB) were included for comparison. Ca- Chaoborus sp., Ce- Ceratopogonidae, Ch1Chironomidae sp.1, Ch2- Chironomidae sp.2, Eph- Campsurus sp., F1- Tetragonopterus argenteus, F2- Astyanax cf. bimaculatus, F3- Parauchenipterus galeatus, F4- Crenicichla sp., F5- Potamorhina squamoralevis, F6- Cyphocharax sp., F7- Anadoras grypus, F8- Leporinus friderici, F9- Steindachnerina brevipinna, Eich- Eichhornia crassipes, Zoo- Zooplankton. The FA 16:1 $\omega 8 c, 16: 1 \omega 8 \mathrm{t}, 16: 1 \omega 6 \mathrm{c}, 16: 1 \omega 5 \mathrm{t}, 18: 1 \omega 8 \mathrm{c}$ and 18:1 $18 \mathrm{t}$ were used as MOB markers. doi:10.1371/journal.pone.0042723.g002

collectors/gatherers [48] and construct their tunnels in soft substrates like mud or sand [49].

b) A cluster of organisms with the highest contributions of 16:1 $18 \mathrm{c}$ which are mainly benthivorous and iliophagous ("mud eaters"; Cyphocharax sp., Chironomidae sp.1, Ceratopogonidae, L. friderici and S. brevipinna). Inside this cluster, two sub-groups emerged: one formed by Cyphocharax sp., Ceratopogonidae and Chironomidae sp.1, and another with $L$. friderici and S. brevipinna. Species of Cyphocharax pick mainly biofilms from the bottom substrates [50]. Larvae of the aquatic insects Ceratopogonidae and Chironomidae rely on different food sources. Some are detritivorous while others may feed also on periphyton [51]. Both families have collector and scraper feeding habits, live close to the bottom and/or associated to roots of aquatic plants [48]. The last two species $L$. friderici and $S$. brevipinna were the most ${ }^{13} \mathrm{C}$ depleted fishes and they have similar feeding habits. Both fishes are iliophagous and feed on detritus, benthic filamentous algae and invertebrates associated to bottom substrates [52,53].

c) Two groups with high contributions of $16: 1 \omega 6 \mathrm{c}$ and $16: 1 \omega 5 \mathrm{t}$ (A. cf. bimaculatus, Crenicichla sp., P. galeatus, Chironomidae sp.2 and $P$. squamoralevis). The group of Chironomidae sp.2 and $P$. squamoralevis showed similar proportions of both fatty acids

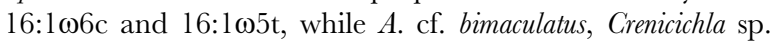
and $P$. galeatus were similar to each other in terms of primarily

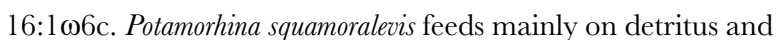
benthic algae and invertebrates associated with bottom sediments [54]. Astyanax bimaculatus is an omnivorous fish which consumes mainly insects [55]. Species of Crenicichla are stalking predators, feeding on insects and fishes [56]. The diet of $P$. galeatus consists mainly of terrestrial and aquatic insects, but also aquatic invertebrates, fishes, fungi, algae, higher plants and detritus [40].

The presence of MOB signature FAs in benthic aquatic insects, planktonic organisms as chaoborids and zooplankton, and fishes showed the importance of biogenic methane to different aquatic compartments in this Pantanal ecosystem (Figure 3). We used a simple two-source mixing model based on ${ }^{13} \mathrm{C}$ signatures to estimate the relative importance of methane-derived carbon as described by Trimmer et al. [22]. Assuming E. crassipes and MOB as end members, it was estimated that methane oxidation contributes on average $13 \%$ and $1 \%$ to the carbon content in fishes from group A and B respectively (Figure 1). However, this value is only an estimate, as the ${ }^{13} \mathrm{C}$ signature of many important carbon sources (phytoplankton, terrestrial DOM from $\mathrm{C}_{3}$ and $\mathrm{C}_{4}$ plants) were not determined and could not be included in this model. The flood pulse also changes the lake dynamics, and may affect the relative importance of MOB for the food chain. We applied the same model for aquatic insects and zooplankton from 


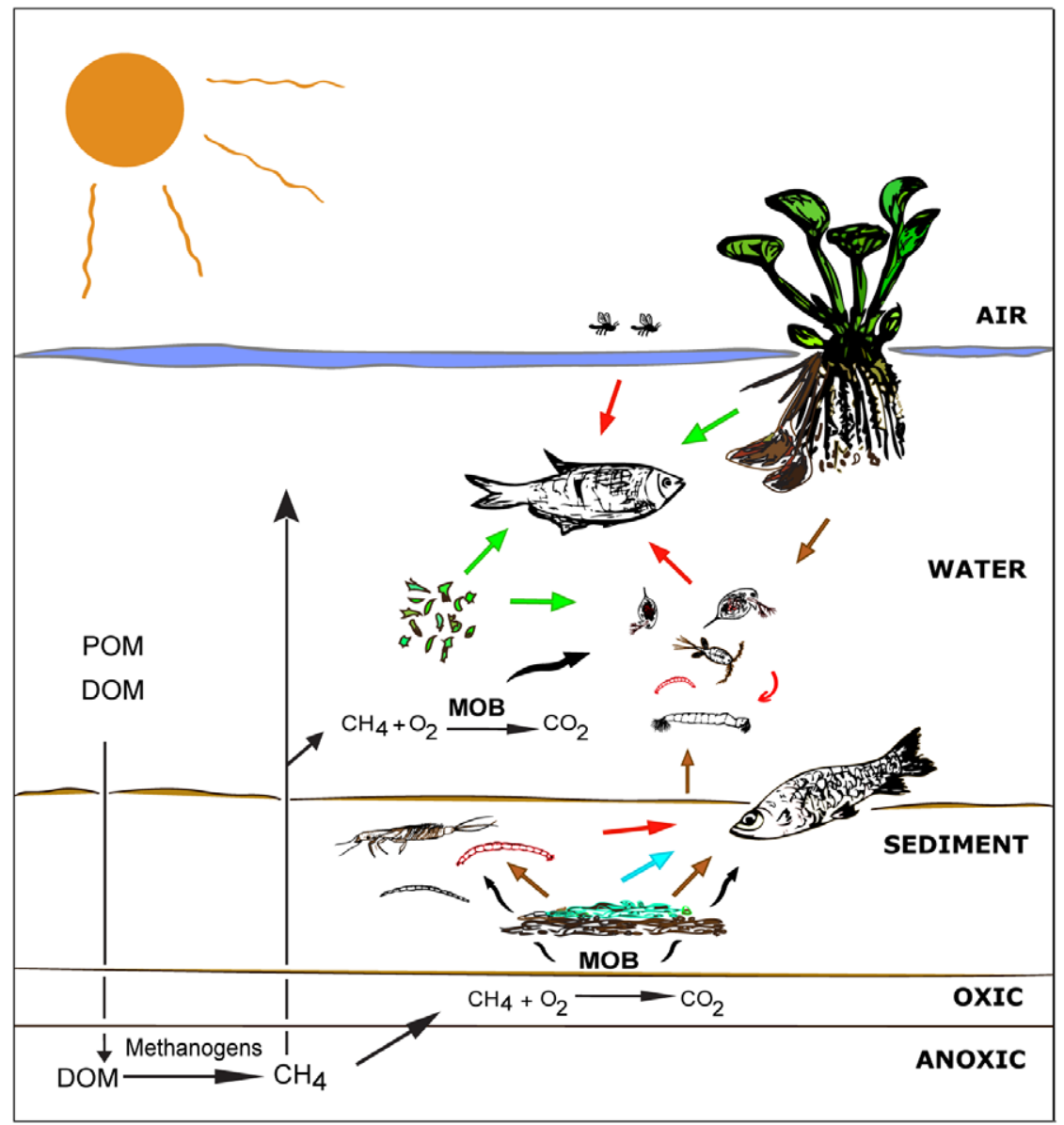

Figure 3. Schematic illustration of the incorporation of carbon of aerobic methane oxidizing bacteria (MOB) into the food web of a tropical shallow lake. Particulate and dissolved organic matter (POM and DOM, respectively) of autochthonous and allochthonous origin support anaerobic methane $\left(\mathrm{CH}_{4}\right)$ formation. $\mathrm{CH}_{4}$ is oxidized by $\mathrm{MOB}$ and $\mathrm{CH}_{4}$-derived carbon is transferred to higher trophic levels subsidizing pelagic and benthic organisms, reaching the fish level. Arrows with different colors indicate potential food sources: black- MOB; green- herbivory on phytoplankton and/or plant material; blue- herbivory on bottom filamentous algae; red- carnivory on aquatic and/or terrestrial organisms; browndetritivory.

doi:10.1371/journal.pone.0042723.g003

this lake and obtained a contribution of $16 \%$ and $22 \%$ as carbon source respectively, a similar value as the results reported by Ravinet et al. [23] and Trimmer et al. [22].

In the present study, the relationship between contribution of MOB FAs and $\delta^{13} \mathrm{C}$ seems to be driven more by the MOB type II FA (18C) than by MOB Type I FAs (16C). It is possible that MOB type II dominates over type I in this wetland and the Pantanal floodplain in general. Sundh et al. [31] pointed out that most studies in temperate and boreal lakes show a predominance of type I over type II, while a few studies reported dominance of MOB type II in tropical freshwaters (e.g. $[57,58])$. Along the same lines, a recent study indicated that type II MOB might drive $\mathrm{CH}_{4}$ oxidation in flood-pulsed wetlands [59].

The two groups of MOB have different growth characteristics and respond differently to variation in temperature, $\mathrm{pH}$ and concentrations of oxygen and methane. Low temperatures seem to favor the development MOB type I over type II [60]. With respect to oxygen and methane supply, MOB type II often dominates at relatively high methane and low oxygen concentrations, while MOB type I dominates at low $\mathrm{CH}_{4}$ and high oxygen concentrations [61].

The Pantanal floodplain is characterized by conditions that together favor production and emissions of $\mathrm{CH}_{4}$, such as high primary productivity, shallow depth of inundation, and high temperature [62]. Such conditions could be expected to be favorable for aerobic methane oxidizers with a probable selection for type II, in line with our results. However, although FAs of MOB type II showed a stronger correlation with ${ }^{13} \mathrm{C}$ signatures, we have to be careful to draw the conclusion that MOB type II dominates fish consumption of MOB in Pantanal as the actual levels of MOB type I and type II FAs in the fishes were overall quite similar.

This study showed, by combining two independent tracers (MOB FA and $\delta^{13} \mathrm{C}$ ), that MOB carbon was transferred through the food web up to the fish level. Hence, our data demonstrate that $\mathrm{CH}_{4}$ can be a significant carbon source not only for the microbial food web and invertebrates, but also for higher trophic levels. The Pantanal region is characterized by high $\mathrm{CH}_{4}$ production [63] and emissions [62], and transfer of $\mathrm{CH}_{4}$ carbon throughout the food web to various fish species could be a common phenomenon in $\mathrm{CH}_{4}$-rich ecosystems.

\section{Materials and Methods}

The Pantanal ecosystem is situated in the Northern part of the Paraguay River basin and is the largest freshwater wetland in 
South America. The Pantanal wetland forms a gradient from areas flooded by rainwater to areas flooded by river water [64]. The strong fluctuations between dry and flood periods throughout the year markedly affect aquatic and terrestrial communities of microand macro-organisms, primary and secondary production as well as nutrient dynamics. The Pantanal region is a very important environment in terms of global methane fluxes because the emissions from their aquatic systems are among the highest rates measured in tropical areas [62].

Different species of fishes, zooplankton, aquatic invertebrates and the aquatic macrophyte Eichhornia crassipes were collected from a shallow lake (average depth $1.8 \mathrm{~m}$ ) in the Paraguay River flood plain near Ladário, Mato Grosso do Sul, Brazil. The fishes were provided by local inhabitants using hand-thrown nets. The captured fishes were killed instantaneously to minimize suffering and we were allowed to document the fish taxonomy and take subsamples immediately after fishing, before further use of the fish by the locals. A piece of fish dorsal muscle was cut out and freeze dried. Zooplankton were collected with a zooplankton net $(150 \mu \mathrm{m}$ mesh), rinsed thoroughly with deionized water, handpicked into $2 \mathrm{ml}$ sterile Eppendorf tubes, and freeze dried. Eichhornia crassipes was the totally dominating macrophyte in and around the lake and whole plants including roots were sampled (this plant is floating and roots are detached from the sediment). The plants were rinsed in water and biofilms were removed from their surfaces. Sediment was collected by diving and sieved for sampling of benthic invertebrates. All benthic invertebrates were kept in filtered (Whatman GF/F) lake water for 24 hours for gut clearance, and were then rinsed and freeze dried.

Samples for stable isotope analysis were analyzed with a Carlo Erba NC2500 analyzer connected to a Finnigan MAT Delta plus mass spectrometer. Carbon stable isotope ratios were reported relative to the PDB (PeeDee Belemnite) standard and expressed as a per mil (\%o) deviation according to the equation $\delta^{13} \mathrm{C}=\left\{\left(\delta^{13} \mathrm{C} /\right.\right.$ $\left.\left.\delta^{12} \mathrm{C}\right)_{\text {sample }} /\left|\left(\delta^{13} \mathrm{C} / \delta^{12} \mathrm{C}\right)_{\text {standard }}-1\right|\right\} \times 1000$. Samples with higher isotope values are relatively enriched in the heavy isotope ${ }^{13} \mathrm{C}$ while samples with lower isotope values are relatively depleted in ${ }^{13} \mathrm{C}$ and enriched in the light isotope ${ }^{12} \mathrm{G}$.

Lipids from biological samples were extracted following the method of Hara and Radin [65]. For GC analysis of fatty acids, the total lipids were methylated according to Appelqvist [66] and the FAMEs (fatty acid methyl ester) were analysed on a Varian CP-3800 Gas Chromatograph system (Agilent Technologies, Santa Clara, CA, USA) using the same column and conditions as in Trattner et al. [67]. Fatty acid peaks were identified by comparison with retention times obtained for the standard fatty acid mixture GLC standard 461 (Nu-Chek Prep, Elysian, MN,

\section{References}

1. Sohngen NL (1906) Über Bakterien, welche Methan als Kohlenstoffnahrung und Energiequelle gebrauchen. Centralbl Bakteriol Parasitenk Infektionskr Abt I 15: 513-517.

2. King GM (1992) Ecological aspects of methane oxidation, a key determinant of global methane dynamics. Adv Microbial Ecol 12: 431-468.

3. Boetius A, Ravenschlag K, Schubert CJ, Rickert D, Widdel F, et al. (2000) A marine microbial consortium apparently mediating anaerobic oxidation of methane. Nature 407: 623-626.

4. Op den Camp HJM, Islam T, Stott MB, Harhangi HR, Hynes A, et al. (2009) Environmental, genomic and taxonomic perspectives on methanotrophic Verrucomicrobia. Environ Microbiol Rep 1: 293-306.

5. Bodelier PLE, Gillisen MJB, Hordijk K, Damsté JSS, Rijpstra WIC, et al. (2009) A reanalysis of phospholipid fatty acids as ecological biomarkers for methanotrophic bacteria. ISME J 3: 606-617.

6. Bowman JP (2006) The methanotrophs - the families Methylococcaceae and Methylocystaceae. In: Dworkin M, Falkow S, Rosenberg E, Schleifer KH, Strackebrandt E, editors. The prokaryotes. New York: Springer. pp. 266-289.
USA). Peak area integration was performed using Star chromatography workstation software version 5.5 (Varian AB, Stockholm, Sweden). The relative contributions of the different double bond positions and isomers of the monounsaturated FAs were determined after DMDS derivatization and GC-MS analyses as described previously $[68,69]$. These data were then used to split the total amounts of monounsaturated FAs obtained in the GCFID analyses of the FAMEs into the different double-bond positions and isomers. The fatty acids $16: 1 \omega 8 \mathrm{c}, 16: 1 \omega 8 \mathrm{t}, 16: 1 \omega 6 \mathrm{c}$,

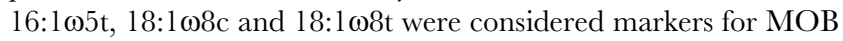
$[5,29,30]$.

A cluster analysis was performed to recognize grouping of organisms according to their contents of the different MOB FA

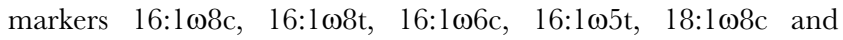
$18: 1 \omega 8 t$ ( $\%$ of total FA) and to identify differences among those groups. The hierarchical clustering was carried out on a BrayCurtis similarity matrix (organisms as objects and MOB FA as descriptors) and represented by a dendrogram produced by UPGMA (Unweighted Pair-Group Method with Arithmetic averages) clustering of this resultant matrix. The cluster analysis was performed using the software package PAST version 2.12 [70].

In order to make an approximation of the relative contribution of $\mathrm{CH}_{4}$-derived carbon for fish, macroinvertebrates and zooplankton, a simple two-source mixing model was used $(x=\{c-b\} /$ $\{a-b\})$ as suggested by Trimmer et al. [22]. We assumed $E$. crassipes (a) and MOB (b) as dietary end members. The $\delta^{13} \mathrm{C}$ values of fish, zooplankton and aquatic insects represented the mixture (c). Trophic fractionation was assumed to be negligible. The $\delta^{13} \mathrm{C}$ values of MOB were derived from methane $\delta^{13} \mathrm{C}$ values measured for the lake (mean: $-80.9 \%$ ) by Conrad et al. [63] with a further fractionation by the MOB of $0-16 \%$ to give a potential range for MOB of -96.9 to $-80.9 \%$ [22,71].

\section{Acknowledgments}

AMS and AEP thank the Brazilian Institute of Environment and Renewable Natural Resources (IBAMA) and Chico Mendes Institute for Biodiversity Conservation (ICMBio)/Ministry of Environment (MMA) for collecting permits no. 17269-1 and 17269-3. The authors would like to thank the two anonymous reviewers and the Academic Editor for their helpful suggestions and comments that improved the manuscript.

\section{Author Contributions}

Conceived and designed the experiments: AEP DB. Performed the experiments: DB IS JP. Analyzed the data: AMS DB IS JP AEP. Wrote the paper: AMS DB IS JP AEP.

7. Pace ML, Cole JJ, Carpenter SR, Kitchell JF, Hodgson JR, et al. (2004) Wholelake carbon-13 additions reveal terrestrial support of aquatic food webs. Nature 427: 240-243

8. Cole JJ, Carpenter SR, Kitchell J, Pace ML, Solomon CT, et al. (2011) Strong evidence for terrestrial support of zooplankton in small lakes based on stable isotopes of carbon, nitrogen, and hydrogen. Proc Natl Acad Sci USA 108: 19751980.

9. Bastviken D (2009) Methane. In: Likens GE, editor. Encyclopedia of inland waters. Oxford: Elsevier. pp. 783-805.

10. Bastviken D, Ejlertsson R, Sundh I, Tranvik L (2003) Methane as a source of carbon and energy for lake pelagic food webs. Ecology 84: 969-981.

11. Jones RI, Grey J (2011) Biogenic methane in freshwater food webs. Freshwater Biol 56: 213-229.

12. Jones RI, Carter CE, Kelly A, Ward S, Kelly DJ, et al. (2008) Widespread contribution of methane-cycle bacteria to the diets of lake profundal chironomid larvae. Ecology 89: 857-864.

13. Fry B (1988) Food web structure on Georges Bank from stable C, N, and S isotopic compositions. Limnol Oceanogr 33: 1182-1190. 
14. Peterson BJ, Fry B (1987) Stable isotopes in ecosystem studies. Ann Rev Ecol Syst 18: 293-320.

15. Bunn SE, Boon PI (1993) What sources of organic carbon drive food webs in billabongs? A study based on stable isotope analysis. Oecologia 96: 85-94.

16. Jones RI, Grey J, Sleep D, Quarmby C (1998) An assessment, using stable isotopes, of the importance of allochthonous organic carbon sources to the pelagic food web in Loch Ness. Proc R Soc Lond B 265: 105-111.

17. Grey J, Jones RI, Sleep D (2000) Stable isotope analysis of the origins of zooplankton carbon in lakes of differing trophic state. Oecologia 123: 232-240.

18. Deines P, Bodelier PLE, Eller G (2007) Methane-derived carbon flows through methane-oxidizing bacteria to higher trophic levels in aquatic systems. Environ Microbiol 9: 1126-1134.

19. Kiyashko SI, Narita T, Wada E (2001) Contribution of methanotrophs to freshwater macroinvertebrates: evidence from stable isotopes. Aquat Microb Ecol 24: 203-207.

20. Grey J, Kelly A, Jones RI (2004) High intraspecific variability in carbon and nitrogen stable isotope ratios of lake chironomid larvae. Limnol Oceanogr 49: 239-244.

21. Kankaala P, Taipale S, Grey J, Sonninen E, Arvola L, et al. (2006) Experimental $\delta^{13} \mathrm{C}$ evidence for a contribution of methane to pelagic food webs in lakes. Limnol Oceanogr 51: 2821-2827.

22. Trimmer M, Hildrew AG, Jackson MC, Pretty JL, Grey J (2009) Evidence for the role of methane-derived carbon in a free-flowing, lowland river food web. Limnol Oceanogr 54: 1541-1547.

23. Ravinet M, Syväranta J, Jones RI, Grey JA (2010) Trophic pathway from biogenic methane supports fish biomass in a temperate lake ecosystem. Oikos 119: 409-416.

24. Wantzen KM, Machado FA, Voss M, Boriss H, Junk WJ (2002) Seasonal isotopic shifts in fish of the Pantanal wetland, Brazil. Aquat Sci 64: 239-251.

25. Calheiros DF (2003) Influência do pulso de inundação na composição isotópica $\left(\delta^{13} \mathrm{C}\right.$ e $\left.\delta^{15} \mathrm{~N}\right)$ das fontes primárias de energia na planície de inundação do rio Paraguai (Pantanal - MS). Unpublished doctoral dissertation, University of São Paulo, Brazil. Website of Embrapa Pantanal. Available: http://www.cpap. embrapa.br/teses/online/TSE05.pdf. Accessed 14 May 2012.

26. Harrod C, Grey J (2006) Isotopic variation complicates analysis of trophic relations within the fish community of Plußsee: a small, deep, stratifying lake. Arch Hydrobiol 167: 281-299.

27. Rau G (1978) Carbon-13 depletion in a subalpine lake: Carbon flow implications. Science 201: 901-902.

28. Grey J, Kelly A, Ward S, Sommerwerk N, Jones RI (2004) Seasonal changes in the stable isotope values of lake-dwelling chironomid larvae in relation to feeding and life cycle variability. Freshwater Biol 49: 681-689.

29. Bowman JP, Sly LI, Nichols PD, Hayward AC (1993) Revised taxonomy of the methanotrophs: description of Methylobacter gen. nov., emendation of Methylococcus, validation of Methylosinus and Methylocystis species, and a proposal that the family Methylococcaceae includes only the group I methanotrophs. Int J Syst Bacteriol 43: 735-753

30. Wise MG, McArthur JV, Shimkets LJ (2001) Methylosarcina fibrata gen. nov, sp. nov. and Methylosarcina quisquiliarum sp. nov, novel type I methanotrophs. Int J Syst Evol Micr 51: 611-621.

31. Sundh I, Bastviken D, Tranvik LJ (2005) Abundance, activity, and community structure of pelagic methane-oxidizing bacteria in temperate lakes. Appl Environ Microbiol 71: 6746-6752.

32. Steger K, Premke K, Gudasz C, Sundh I, Tranvik LJ (2011) Microbial biomass and community composition in boreal lake sediments. Limnol Oceanogr 56: 725-733.

33. Iverson SJ (2009) Tracing aquatic food webs using fatty acids: from qualitative indicators to quantitative determination. In: Arts MT, Brett MT, Kainz MJ, editors. Lipids in aquatic ecosystems. New York: Springer. pp. 281-307.

34. Goedkoop W, Sonesten L, Markensten H, Ahlgren G (1998) Fatty acid biomarkers show dietary differences between dominant chironomid taxa in Lake Erken. Freshwater Biol 40: 135-143.

35. Taipale S, Kankaala P, Hämäläinen H, Jones RI (2009) Seasonal shifts in the diet of lake zooplankton revealed by phospholipid fatty acid analysis. Freshwater Biol 54: 90-104

36. Kiyashko SI, Imbs AB, Narita T, Svetashev V, Wada E (2004) Fatty acid composition of aquatic insect larvae Stictochironomus pictulus (Diptera: Chironomidae): evidence of feeding upon methanotrophic bacteria. Comp Biochem Phys B 139: 705-711.

37. Oliveira ERN, Agostinho AA, Matsushita M (2003) Effect of biological variables and capture period on the proximate composition and fatty acid composition of the dorsal muscle tissue of Hypophthalmus edentatus (Spix, 1829). Braz Arch Biol Technol 46: 105-114.

38. Arrington DA, Davidson BK, Winemiller KO, Layman CA (2006) Influence of life history and seasonal hydrology on lipid storage in three neotropical fish species. J Fish Biol 68: 1347-1361.

39. Resende EK, Pereira RAC, Almeida VLL, Silva AG (2000) Peixes onívoros da planície inundável do Rio Miranda, Pantanal, Mato Grosso do Sul, Brasil. Embrapa Bol Pesq 16: 1-44.

40. Peretti D, Andrian IF (2008) Feeding and morphological analysis of the digestive tract of four species of fish (Astyanax altiparanae, Parauchenipterus galeatus, Serrasalmus marginatus and Hoplias aff. malabaricus) from the upper Paraná River floodplain, Brazil. Braz J Biol 68: 671-679.
41. Raghoebarsing AA, Smolders AJP, Schmid MC, Rijpstra IC, Wolters-Arts M, et al. (2005) Methanotrophic symbionts provide carbon for photosynthesis in peat bogs. Nature 436: 1153-1156.

42. Kip N, van Winden JF, Pan Y, Bodrossy L, Reichart G, et al. (2010) Global prevalence of symbiotic bacterial methane oxidation in peat moss ecosystems. Nat Geosci 3: 617-621.

43. Corrêa CE, Albrecht MP, Hahn NS (2011) Patterns of niche breadth and feeding overlap of the fish fauna in the seasonal Brazilian Pantanal, Cuiabá River basin. Neotrop Ichthyol 9: 637-646.

44. Pereira PR, Agostinho CS, Oliveira RJ, Marques EE (2007) Trophic guilds of fishes in sandbank habitats of a Neotropical river. Neotrop Ichthyol 5: 399-404.

45. Sæther OA (1997) Diptera Chaoboridae, phantom midges. In: Nilsson A, editor. Aquatic insects of North Europe - A taxonomic handbook. Volume 2. OdonataDiptera. Stenstrup: Apollo Books. pp. 149-161.

46. Arcifa MS (2000) Feeding habits of Chaoboridae larvae in a tropical Brazilian reservoir. Rev Brasil Biol 60: 591-597.

47. Correa SB (2005) Comparison of fish assemblages in flooded forest versus floating meadows habitats of an upper Amazon floodplain (Pacaya Samiria National Reserve, Peru) MSc. thesis, University of Florida. Website of the Florida Museum of Natural History, Project Ucamara. Available: http://www. flmnh.ufl.edu/ucamara/pubs/correa_2005.pdf. Accessed 10 February 2011

48. Merritt RW, Cummins KW (1996) An introduction to the aquatic insects of North America. Dubuque: Kendall Hunt Publishing Co. 862 p.

49. Molineri C, Emmerich D (2010) New species and new stage descriptions of Campsurus major species group (Polymitarcyidae: Campsurinae), with first report of silk-case construction in mayfly nymphs. Aquat Insects: Internat J Freshwater Entomol 32: 265-280.

50. Vari RP (1992) Systematics of the Neotropical characiform genus Cyphocharax Fowler (Pisces: Ostariophysi). Smithsonian Contrib Zool 529: 1-137.

51. Coffman WP, Ferrington LC Jr (1996) Chironomidae. In: Merrit RW, Cummins KW, editors. An introduction to the aquatic insects of North America. Dubuque: Kendall Hunt Publishing Co. pp. 635-754.

52. Albrecht MP, Caramaschi EP (2003) Feeding ecology of Leporinus friderici (Teleostei; Anostomidae) in the upper Tocantins River, Central Brazil, before and after installation of a hydroelectric plant. Stud Neotrop Fauna Environ 38: 33-40.

53. Lopes CA, Benedito E, Martinelli LA (2009) Trophic position of bottom-feeding fish in the upper Paraná River floodplain. Braz J Biol 69: 573-581.

54. Pereira RAC, Resende EK (1998) Peixes detritívoros da planície inundável do Rio Miranda, Pantanal, Mato Grosso Do Sul, Brasil. Embrapa Bol Pesq 12: 150.

55. Esteves KE, Galetti PM (1995) Food partitioning among some characids of a small Brazilian floodplain lake. Environ Biol Fishes 42: 375-389.

56. Sazima I (1986) Similarities in feeding behaviour between some marine and freshwater fishes in two tropical communities. J Fish Biol 29: 53-65.

57. Dumestre JF, Vaquer A, Gosse P, Richard S, Labroue L (1999) Bacterial ecology of a young equatorial hydroelectric reservoir (Petit Saut, French Guiana). Hydrobiologia 400: 75-83.

58. Dumestre JF, Casamayor EO, Massana R, Pedrós-Alió C (2001) Changes in bacterial and archaeal assemblages in an equatorial river induced by the water eutrophication of Petit Saut dam reservoir (French Guiana). Aquat Microb Ecol 26: 209-221.

59. Chowdhury TR, Dick R (2011) Type II aerobic methane oxidizing bacteria (AMOB) drive methane oxidation in pulsed wetlands as indicated by $13 \mathrm{C}$ phospholipid fatty acid composition. Available from Nature Precedings <http://dx.doi.org/10.1038/npre.2011.6291.1> Accessed 07 June 2012.

60. Börjesson G, Sundh I, Svensson B (2004) Microbial oxidation of $\mathrm{CH}_{4}$ at different temperatures in landfill cover soils. FEMS Microbiol Ecol 48: 305-312.

61. Amaral JA, Knowles R (1995) Growth of methanotrophs in methane and oxygen counter gradients. FEMS Microbiol Lett 126: 215-220.

62. Bastviken D, Santoro AL, Marotta H, Pinho LQ Calheiros DF, et al. (2010) Methane emissions from Pantanal, South America, during the low water season: toward more comprehensive sampling. Environ Sci Technol 44: 5450-5455.

63. Conrad R, Noll M, Claus P, Klose M, Bastos WR, et al. (2011) Stable carbon isotope discrimination and microbiology of methane formation in tropical anoxic lake sediments. Biogeosciences 8: 795-814.

64. Junk WJ, Furch K (1993) A general review of tropical South American floodplains. Wetlands Ecol Manage 2: 231-238.

65. Hara A, Radin NS (1978) Lipid extraction of tissue with low toxicity solvent. Anal Biochem 90: 420-426.

66. Appelqvist L-Å (1968) Rapid methods of lipid extractions and fatty acid methyl ester preparation for seed and leaf tissue with special remarks on preventing the accumulation of lipids contaminants. Ark Kemi 28: 551-570.

67. Trattner S, Ruyter B, Østbye TK, Gjøen T, Zlabek V, et al. (2008) Sesamin increases alpha-linolenic acid conversion to docosahexaenoic acid in Atlantic salmon (Salmo salar L.) hepatocytes: Role of altered gene expression. Lipids 43: 999-1008.

68. Nichols PD, Guckert JB, White DC (1986) Determination of monounsaturated fatty acid double-bond position and geometry for microbial monocultures and complex consortia by capillary GC-MS of their dimethyl disulphide adducts. J Microbiol Meth 5: 49-55.

69. Virtue P, Nichols PD, Boon PI (1996) Simultaneous estimation of microbial phospholipid fatty acids and diether lipids by capillary gas chromatography. J Microbiol Meth 25: 177-185. 
70. Hammer Ø, Harper DAT, Ryan PD (2001) PAST: Paleontological Statistics Software Package for Education and Data Analysis. Palaeont Electron 4: 1-9.
71. Summons RE, Jahnke LL, Roksandic Z (1994) Carbon isotopic fractionation in lipids from methanotrophic bacteria: Relevance for interpretation of the geochemical record of biomarkers. Geochim Cosmochim Acta 58: 2853-2863. 